\title{
FAKTOR AYAH DAN IBU YANG BERKONTRIBUSI TERHADAP MUNCULNYA GEJALA PERILAKU DISRUPTIF REMAJA
}

\author{
Nandy Agustin Syakarofath ${ }^{1}$, Subandi Subandi ${ }^{2}$ \\ ${ }^{1)}$ Fakultas Psikologi, Universitas Muhammadiyah Malang \\ J1. Raya Tlogomas No. 246 Malang, Indonesia \\ ${ }^{2)}$ Fakultas Psikologi, Universitas Gadjah Mada, \\ Jl. Sosio Humaniora Bulaksumur Yogyakarta, Indonesia \\ nandysyakarofath@umm.ac.id
}

\begin{abstract}
Disruptive behavior according to DSM 5 is a pattern of behavior that violates the rights of others, aggression, property destruction and or that leads individuals to experience significant conflicts with violations of social norms or authority figures. This study aims to examine the significance of two factors derived from the family towards the emergence of disruptive behavior that are the family expressed emotion and perceived of parentchild relationships. There are 237 teenagers was participated in this study (aged 15-18 years old) who lived with their parent obtained from the scaling of SDQ, LEE and PACQ. The result of the regression indicated the two predictors explained 5,3\% of variance (adjusted $R^{2}=.053, F(3.235)=.013, p<.05$ ). The implications of this study are the family expressed emotion and perceived of parent-child relationships are two factors that can contributed to the emergence of disruptive behavior symptoms in adolescent, although if analyzed separately perceived of parent-child relationships towards a mother has no effect.
\end{abstract}

Keywords: disruptive behavior; family expressed emotion; perceived of parent-child relationships

\begin{abstract}
Abstrak
Perilaku disruptif menurut DSM 5 adalah pola perilaku melanggar hak orang lain, agresi, perusakan properti dan perilaku yang membawa individu mengalami konflik yang signifikan dengan pelanggaran norma sosial atau figur otoritas. Penelitian ini bertujuan untuk menguji signifikansi dua faktor yang berasal dari keluarga terhadap munculnya perilaku disruptif yaitu ekspresi emosi keluarga dan persepsi hubungan orangtua-anak. Sampel penelitian ini adalah 237 remaja yang berusia 15-18 tahun dan tinggal dengan orangtua mereka yang didapatkan dari pemberian skala SDQ, LEE, dan PACQ. Berdasarkan hasil perhitungan analisis regresi berganda kedua variabel prediktor penelitian ini menjelaskan adanya peran sebesar 5,3\% dengan varians (adjusted $R^{2}=0,053$, $F(3,235)=0,013, p<0,05)$. Implikasi dari penelitian ini adalah ekspresi emosi orangtua dan persepsi hubungan orangtua anak adalah dua faktor yang dapat berkontribusi terhadap munculnya gejala perilaku disruptif remaja, meskipun jika di analisis secara terpisah persepsi hubungan orangtua anak terhadap ibu tidak memiliki peran yang signifikan.
\end{abstract}

Kata kunci: perilaku disruptif; ekspresi emosi keluarga; persepsi hubungan orangtua-anak

\section{PENDAHULUAN}

Tindakan kriminalitas di Indonesia sangat tinggi. Berdasarkan data yang diperoleh Badan Pusat Statistik Kriminal (2014) jumlah kejahatan yang dilaporkan (crime total) menurut catatan Biro Pengendalian Operasi Mabes Polri sejak tahun 2011-2013 mencapai angka 1.030.848 kasus yang terjadi di seluruh wilayah Indonesia. Adapun bentuk kriminalitas yang dilakukan adalah tindakan kekerasan dan penganiayaan, kejahatan asusila, pencurian dan perusakan barang serta penyalahgunaan zat.

Bentuk kriminalitas yang telah disebutkan, umumnya tindakan yang merepresentasikan adanya masalah perilaku yang dialami pada masa kanak-kanak dan remaja. Menurut Hammerton dkk., (2019) dan Odgers dkk., (2008) masalah perilaku yang terjadi di masa kanak-kanak dapat memprediksi masalah 
terkait kesehatan mental di masa remaja dan dewasanya. Masalah kesehatan mental yang dimaksud di dalam penelitian tersebut adalah masalah terkait penyalahgunaan zat, masalah hukum seperti risiko penangkapan, masalah pendidikan misalnya drop-out dari sekolah, masalah sosial misalnya kesulitan di dalam penyesuaian perkawinan, masalah kerja misalnya kinerja pekerjaan yang buruk, dan masalah kesehatan fisik misalnya fungsi pernafasan yang kurang baik.

Ada berbagai jenis kriminalitas terkait remaja. Badan Pusat Statistik Kriminal (2010) memaparkan bahwa jenis tindak pidana atau kenakalan yang dilakukan remaja di Indonesia adalah kepemilikan senjata tajam, narkoba, perkosaan/ pencabulan, pengeroyokan, pembunuhan, penganiayaan, kecelakaan lalu lintas fatal, pencurian, pemerasan dan penggelapan, penadah hasil kejahatan dan berbagai jenis tindak pidana lainnya. Beragamnya kasus kriminalitas yang dilakukan remaja tersebut biasanya sering dikaitkan dengan kenakalan remaja, artinya remaja yang melakukan kriminalitas mendapatkan label anak yang nakal. Selanjutnya, dalam konteks masyarakat kenakalan anak-anak atau remaja dapat diistilahkan dengan perilaku disruptif (Loeber, Burke \& Pardini, 2009).

Istilah yang dapat menggambarkan perilaku disruptive beragam. Menurut Matthys dan Lochman (2010) perilaku disruptif disebut juga dengan perilaku yang tidak pantas atau inapproriate behavior. Biasanya perilaku disruptive sering diperlihatkan oleh anakanak atau remaja di dalam aktivitas sehari hari dan sifatnya mengganggu. Hal ini sejalan dengan temuan Asizah (2015) bahwa perilaku yang tidak pantas yang biasa ditemukan dalam keseharian anak dan remaja adalah perilaku yang sifatnya negatif baik secara verbal dan non-verbal, seperti mengamuk, menuntut perhatian, tidak patuh, melawan, melakukan agresivitas yang dapat membahayakan diri sendiri atau orang lain, mencuri, berbohong, dan perilaku mengganggu lainnya. Mendukung penelitian tersebut Bulotsky-shearer, Dominguez, Bell, Rouse, dan Fantuzzo (2010) menambahkan bahwa masalah perilaku disruptif tahap awal dapat memprediksi masalah sosial emosi pada anak yang lebih besar di kemudian hari.

Bentuk perilaku disruptif bermacam-macam dan luas maknanya. Berdasarkan DSM 5 perilaku disruptif disebut sebagai bentuk perilaku yang tidak pantas yang sifatnya lebih umum, bertahan lama, dan dapat berkembang sesuai tingkat keparahannya menjadi oppositional defiant disorder (ODD) ataupun conduct disorder (CD). Hal ini disebabkan karena ODD maupun CD merupakan bagian dari kelompok perilaku disruptive behavior disorders (Christenson, Crane, Malloy \& Parker, 2016; Pringsheim, Hirsch, Gardner, \& Gorman, 2015). Artinya anak atau remaja yang mengalami perilaku disruptive juga menunjukkan perilaku bermasalah yang merepresentasikan adanya gejala oppositional defiant disorder (ODD) maupun conduct disorder (CD) (American Psychiatric Association, 2013).

Cara menentukan sebuah perilaku untuk dapat dikatakan disruptif, perlu dilihat dari ciri-ciri perilakunya. Shepherd (2010) memaparkan bahwa ciri dari perilaku bermasalah anak-anak dan remaja ditandai dengan intensitas kemunculan perilaku tersebut, biasanya lebih sering dibandingkan dengan anak normal lainnya, lebih lama, lebih kuat dan sifatnya khas. Perilaku bermasalah tersebut meliputi perilaku agresif, perusakan (destructive), menipu atau berbohong yang dilakukan sebelum usia 18 tahun selama minimal 6 bulan atau selama 12 bulan terakhir (Wenar \& Kerig, 2012; Reinke \& Herman, 2002). Artinya, untuk membedakan antara masalah perilaku yang wajar dan tidak wajar pada remaja dapat dilihat dari seberapa sering masalah perilaku tersebut muncul, menetap atau tidak, dan minimal harus terlihat selama 6 hingga 12 bulan terakhir. Selain itu, masalah perilaku yang tak wajar juga menyebabkan kerugian atau dampak negatif terhadap individu itu sendiri dan orang lain. 
Mendukung pemaparan tersebut, karakteristik perilaku disruptif dibagi menjadi dua bagian, yaitu karakteristik umum dan karakteristik khusus. Menurut Buitelaar dkk., (2013); Frank-briggs, Alikor, dan Harcourt (2008) karakteristik umum masalah perilaku ditunjukkan dengan aktivitas fisik yang intens, mengganggu teman sepermainan, berkelahi dan perilaku melawan. Pada umumnya perilaku tersebut akan mudah kita jumpai di berbagai lingkungan dan komunitas anak-anak remaja seperti di sekolah, di rumah dan di lingkungan bermain. Sedangkan pada karakteristik khusus ditandai dengan tingkah laku agresivitas, berperilaku merusak, melanggar aturan, dan berperilaku anti sosial yang menyebabkan dampak yang merugikan bagi anak tersebut dan orang lain yang berada di lingkungannya seperti rumah, sekolah, dan tempat ibadah.

Ada berbagai faktor yang dapat memicu munculnya gejala perilaku disruptif pada anak-anak dan remaja. Menurut Dobmeier dan Moran (2008) faktor yang berkontribusi terhadap munculnya perilaku disruptif yaitu disabilitas, latar belakang sosial-ekonomi, pengalaman kekerasan yang pernah dialami, stres yang disebabkan pengasuhan dan tuntutan pekerjaan, lingkungan belajar dan informasi yang tidak memadai. Secara umum, faktor yang menyebabkan masalah perilaku tersebut dapat dibagi menjadi dua yaitu faktor internal dan faktor eksternal. Faktor internal adalah faktor yang berasal dari diri anak itu sendiri seperti adanya disabilitas sedangkan faktor eksternal adalah faktor yang berasal dari lingkungan misalnya latar belakang sosial-ekonomi, pengalaman kekerasan yang pernah dialami anak atau remaja, stres yang disebabkan pengasuhan dan tuntutan pekerjaan, lingkungan belajar, dan informasi yang tidak memadai.

Faktor penyebab perilaku disruptif yang menjadi fokus kajian yang akan dilakukan adalah faktor eksternal. Pada faktor eksternal menurut Berkout, Young, dan Gross (2011) salah satu komponen yang berkontribusi terhadap munculnya masalah perilaku yaitu problem yang berkaitan pengasuhan orangtua, seperti adanya keterlibatan yang kurang dengan kehidupan anak, tidak bisa memelihara konflik atau permusuhan di depan anak, dan disiplin yang tidak konsisten. Dengan demikian dapat dipahami bahwasanya pengasuhan yang berdampak negatif terhadap anak dan remaja adalah pengasuhan yang sifatnya negatif.

Sejalan dengan pemaparan tersebut Huang dkk., (2019) menambahkan bahwa problem pengasuhan yang negatif berdampak terhadap masalah perilaku anak jika anak memersepsikan hubungan dengan orangtuanya secara negatif. Pada umumnya, ada dua arah bentuk persepsi hubungan orangtuaanak yaitu persepsi positif dan persepsi negatif. Seperti yang disampaikan Pitzer, Fingerman, dan Lefkowitz (2011) ada dua karakteristik hubungan orangtua-anak yaitu hubungan yang memiliki kualitas yang positif atau negatif. Artinya masalah pengasuhan berdampak negatif jika anak memersepsikan hubungan dengan orangtuanya secara negatif, tetapi akan menjadi positif dampaknya jika anak memersepsikan dengan positif.

Yang dimaksud dengan persepsi hubungan orangtua-anak, menurut Fuligni dan Eccles (1993) adalah bagaimana cara anak memersepsikan kualitas hubungan yang terjalin dengan orangtua mereka. Kualitas hubungan tersebut dapat dilihat dari interaksi kedua belah pihak (orangtua-anak), komunikasi, dan atmosfer kehangatan di dalam keluarga. Mendukung pemaparan tersebut Tam, Lee, Kumasuriar, dan Har (2012) menyampaikan bahwa persepsi hubungan orangtua-anak tidak hanya hubungan yang terbentuk karena ikatan biologis orangtua-anak semata, tetapi juga termasuk ikatan psikologis dan hubungan sosial di antara mereka. Dengan demikian dapat dipahami bahwa hubungan orangtuaanak adalah hubungan yang terikat dengan satu kesatuan komponen berupa ikatan 
biologis, psikologis, dan sosial di antara keduanya.

Faktor lain di dalam pengasuhan selain hubungan orangtua-anak yang berperan terhadap munculnya masalah perilaku pada anak adalah ekspresi emosi keluarga. Menurut Hastings dan Lloyd (2007) ekspresi emosi orangtua kepada anak dapat mempertahankan atau memperburuk masalah perilaku yang dihadapi anak. Artinya ekspresi emosi yang tinggi dan kerap kali dimunculkan oleh orangtua terhadap anak berdampak negatif yaitu munculnya masalah perilaku di kemudian hari.

Untuk dapat memahami ekspresi emosi keluarga (family expressed emotion), Amaresha dan Venkatasubramanian (2017) mendefinisikan dengan lingkungan keluarga yang merugikan, yaitu meliputi kualitas pola interaksi dan sifat hubungan keluarga yang muncul sehari-hari. Biasanya, ekspresi emosi ditujukan oleh antar anggota keluarga khususnya individu yang melakukan perawatan atau pengasuhan kepada individu yang dirawat atau diasuh.

Pertama kali konsep ekspresi emosi keluarga (family expressed emotion) dikenal sejak dilakukan penelitian oleh Brown dan kawankawannya pada tahun 1956 terhadap pasien yang dirawat di rumah sakit yang mengalami skizofrenia kemudian dikembalikan kepada keluarganya cenderung mengalami kekambuhan dibandingkan dengan pasien yang tinggal di tempat lain (Kanter, Lamb, \& Loeper, 1987). Penelitian-penelitian tersebut mengamati tingkat keterlibatan emosional yang tinggi (high emotinal involvement) keluarga terhadap pasien cenderung memperburuk kondisi pasien dan membuat pasien rentan mengalami kekambuhan (Zanetti dkk., 2018). Dengan demikian yang dimaksud dengan ekspresi emosi keluarga (family expressed emotion) adalah gambaran kualitas afeksi antar anggota keluarga dalam kehidupan sehari-hari.
Ekspresi emosi keluarga berdasarkan temuannya sering diasosiasikan dengan masalah psikologis. Menurut Peris dan Miklowitz (2015) ekspresi emosi telah lama dipelajari sebagai faktor risiko yang berasal dari pengasuhan orangtua terhadap munculnya berbagai masalah psikologis anak. Hal ini dibuktikan dengan berbagai penelitian yang memaparkan bahwasanya ekspresi emosi keluarga berkaitan dengan skizofrenia (Carrà, Cazzullo, \& Clerici, 2012), psikosis (Subandi, 2011; Vasconcelos e Sa, Wearden, \& Barrowclough, 2013), obsessive compulsive (Przeworski dkk., 2012), ADHD (Kronenberg dkk., 2016), depresi (Asarnow, Tompson, Woo, \& Cantwell, 2001), gangguan makan (Schmidt, Tetzlaff, \& Hilbert, 2015), penggunaan alkohol (Njango, Merecia, \& Christine, 2016), demensia (Yu, Kwok, Choy, \& Kavanagh, 2016) dan bipolar disorder (Shimodera, Yonekura, Yamaguchi, Kawamura, \& Mizuno, 2012). Pada umumnya ekspresi emosi tersebut berupa komentar kritikan yang diberikan oleh ibu (Hale dkk., 2016; Przeworski dkk., 2012; Tompson dkk., 2010; Boger dkk.,2008).

Berdasarkan uraian di atas dapat diketahui bahwa hubungan orangtua-anak dan ekspresi emosi keluarga berperan terhadap munculnya masalah perilaku anak seperti perilaku yang disruptif. Fenomena ini merupakan hal serius yang saat ini dihadapi oleh masyarakat, mengingat tingginya angka tren kenakalan dan kriminalitas remaja. Dengan mengetahui hubungan antara ketiga variabel tersebut melalui penelitian ini dapat menjadi sumber informasi yang berbasis ilmiah bagi berbagai pihak untuk dapat melakukan antisipasi sedini mungkin agar anak tidak mengalami pengalaman yang negatif saat berada dalam masa pengasuhan atau perawatan orangtua mereka. Harapannya perilaku anak menjadi lebih adaptif dan dapat diterima oleh lingkungan sosial. 


\section{METODE}

Penelitian ini dilakukan dengan menggunakan metode kuantitatif. Subjek penelitian adalah 237 siswa yang terdaftar di tiga sekolah menengah atas di Kabupaten Pamekasan Madura dengan rentang usia 1518 tahun dan tinggal dengan orangtua (baik ayah maupun ibu). Teknik pengambilan sampel menggunakan purposive sampling, dengan karakteristik sampel adalah: 1) remaja yang berusia 15-18 tahun (duduk di bangku SMA), 2) terdaftar sebagai siswa di sekolah yang tidak menjadi tujuan utama para orangtua di Pamekasan untuk menyekolahkan anak-anaknya, 3) tinggal di rumah dengan ayah dan ibu.

Data dikumpulkan dengan menggunakan tiga skala yaitu: 1) the strengths and difficulties questionnaire $(S D Q)$ yang dikembangkan oleh Goodman, Meltzer, \& Bailey (1998) digunakan untuk mendeteksi gejala perilaku disruptive $(\alpha=0,82)$, alat skrining tersebut sudah diterjemahkan ke dalam berbagai bahasa di dunia termasuk Bahasa Indonesia (Wiguna, Manengkei, Pamela, Rheza, \& Hapsari, 2010), 2) the level of expressed emotion scale (LEE) yang diadaptasi oleh Subandi (2011) untuk mengukur ekspresi emosi keluarga, adapun skala ini terbagi menjadi dua jenis skala yaitu level ekspresi emosi ibu (LEE ibu) dengan $(\alpha=0,810)$ dan level ekspresi emosi pada ayah dengan $(\alpha=$ 0,851), dan 3) the parent adult-child relationship questionnaire (PACQ) untuk mengukur persepsi hubungan orangtua-anak yang dibuat berdasarkan Peisah, Brodaty, Luscombe, Kruk, dan Anstey (1999) dengan mengukur persepsi hubungan orangtua-anak terhadap ibu pada faktor regards $(\alpha=0,87)$ dan responsibility $(\alpha=0,82)$ serta persepsi hubungan orangtua-anak terhadap ayah pada faktor regards $(\alpha=0,86)$, responsibility $(\alpha=$ $0,74)$ dan $(\alpha=$ control 0,87$)$.

Analisa data dalam penelitian ini menggunakan teknik regresi berganda, untuk menguji hipotesis penelitian. Teknik regresi berganda adalah cara menganalisis data dengan memprediksikan variabel hasil dari beberapa variabel prediktor (Field, 2011). Proses pengolahan data yang dilakukan menggunakan program IBM statistik SPSS (Statistical Program For Social Science) for Windows versi 22. Sebelum melakukan uji hipotesis melalui regresi berganda terlebih dahulu akan dilakukan uji asumsi berupa uji normalitas, linearitas dan multikolinearitas.

\section{HASIL DAN PEMBAHASAN}

Dari 237 responden yang menjadi subjek penelitian terdapat sejumlah 135 siswa lakilaki dan 102 siswa perempuan. Pengambilan data dilakukan dengan menyebarkan skala ke beberapa sekolah tujuan penelitian. Usia subjek penelitian keseluruhan bervariasi dari rentang 15-18 tahun. Secara terperinci lihat tabel 1.

Hasil perhitungan analisis regresi berganda kedua variabel prediktor penelitian menjelaskan adanya peran sebesar $5,3 \%$ dengan varians (adjusted $R^{2}=0,053$, $F(3,235)=0,013, p<0,05)$. Artinya, secara simultan ekspresi emosi keluarga dan persepsi hubungan orangtua anak berperan terhadap munculnya gejala perilaku disruptif, dengan sumbangan efektif sebesar 5,3\%.

Tabel 1.

Karakteristik Subjek

\begin{tabular}{ccccc}
\hline & & Jumlah & Persentase & Total Persentase \\
\hline \multirow{2}{*}{ Jenis Kelamin } & Laki-laki & 135 & $57 \%$ & \multirow{2}{*}{$100 \%$} \\
& Perempuan & 102 & $43 \%$ & \\
\multirow{3}{*}{ Usia } & 15 tahun & 13 & $5,5 \%$ & \multirow{2}{*}{$100 \%$} \\
& 16 tahun & 112 & $47,3 \%$ & \\
& 17 tahun & 96 & $40,5 \%$ & \\
& 18 tahun & 16 & $6,8 \%$ & \\
\hline
\end{tabular}


Secara terpisah, ekspresi emosi ibu terhadap munculnya gejala perilaku disruptif $(\beta=$ $0,198 ; p<0,01)$ dan ekspresi emosi ayah terhadap munculnya gejala perilaku disruptif $(\beta=0,149 ; p<0,05)$. Hasil ini menunjukkan bahwa semakin tinggi skor ekspresi emosi ibu maupun ekspresi emosi ayah maka semakin tinggi skor munculnya gejala perilaku disruptif remaja.

Berbeda dengan hal tersebut, persepsi hubungan orangtua-anak kepada ibu terhadap munculnya gejala perilaku disruptif $(\beta=-0,100 ; p>0,05)$. Hasil menunjukkan persepsi hubungan orangtua-anak terhadap ibu tidak memiliki hubungan terhadap munculnya gejala perilaku disruptif remaja. Sedangkan persepsi hubungan orangtua-anak kepada ayah memiliki hubungan terhadap munculnya perilaku disruptif remaja ( $\beta=$ $0,145 ; p<0,05)$. Dengan demikian dapat dikatakan bahwa semakin tinggi persepsi hubungan orangtua-anak terhadap ayah semakin rendah munculnya gejala perilaku disruptive remaja. Secara terperinci dapat dilihat pada tabel 2 .

Tabel 2.

Penjabaran Model Regresi dari Variabel Penelitian

Model $\quad R^{2} \quad$ Sig

Ekspresi emosi ibu, ekspresi emosi ayah, persepsi hubungan orangtua anak berdasarkan ibu dan persepsi hubungan orangtua anak berdasarkan ayah terhadap gejala perilaku disruptif

\begin{tabular}{lcc}
\hline \multicolumn{1}{c}{ Model } & Beta & Sig \\
\hline Ekspresi emosi ibu dan perilaku disruptif & 0,198 & $0,002^{* *}$ \\
$\begin{array}{l}\text { Ekspresi emosi ayah dan perilaku disruptif } \\
\text { persepsi hubungan orangtuaanak terhadap ibu }\end{array}$ & 0,149 & $0,022^{*}$ \\
$\begin{array}{l}\text { dan perilaku disruptif } \\
\text { persepsi hubungan orangtua anak terhadap }\end{array}$ & $-0,100$ & 0,125 \\
ayah dan perilaku disruptif & $-0,145$ & $0,025^{*}$ \\
\hline
\end{tabular}

Keterangan: ${ }^{* *} p<0,01 * p<0,05$

Temuan yang didapat membuktikan bahwa ekspresi emosi keluarga dan persepsi hubungan orangtua-anak secara simultan dapat berperan terhadap munculnya gejala perilaku disruptif remaja. Baik itu ekspresi emosi ibu, ekspresi emosi ayah, persepsi hubungan orangtua-anak terhadap ibu dan persepsi hubungan orangtua-anak terhadap ayah. Namun, jika dilihat secara terpisah ekspresi emosi ibu, ekspresi emosi ayah dan persepsi hubungan orangtua-anak terhadap ayah dapat berperan terhadap munculnya gejala perilaku disruptive remaja, sedangkan persepsi hubungan orangtua-anak terhadap ibu tidak berperan.
Berdasarkan hasil perhitungan regresi berganda, ekspresi emosi ibu diketahui sebagai faktor yang paling berperan terhadap munculnya gejala perilaku disruptif remaja dibandingkan ekspresi emosi ayah dan persepsi hubungan orangtua-anak terhadap ayah. Hubungan positif antara ekspresi emosi keluarga dan perilaku disruptif yang ditemukan dalam penelitian ini sesuai dengan penelitian yang dilakukan oleh Bader, Barry, dan Hann (2015) yang mengatakan bahwa ekspresi emosi orangtua adalah lingkungan keluarga yang penting dan berperan terhadap masalah eksternalisasi perilaku anak. Selanjutnya, Baker dkk., (2000) menyebutkan ekspresi emosi keluarga yang paling berkontribusi terhadap 
munculnya gangguan perilaku pada anak adalah ekspresi emosi ibu. Penelitian lain yang mendukung temuan tersebut juga menyebutkan bahwa ekspresi emosi yang berasal dari ibu, khususnya komentar kritikan merupakan faktor risiko yang kuat di dalam memunculkan psikopatologi pada anak (McCarty, Lau, Valeri, \& Weisz, 2004; Tompson dkk., 2010; Przeworski dkk., 2012; Han \& Shaffer, 2014; Hale dkk., 2016).

Secara umum, tidak hanya ekspresi emosi ibu saja tetapi secara keseluruhan ekspresi emosi keluarga berdasarkan beberapa literatur disebutkan dapat menjadi faktor yang dapat memprediksi masalah perilaku anak. Hal ini sesuai dengan Peris dan Baker (2000) bahwa ekspresi emosi keluarga secara simultan dan berkelanjutan memiliki hubungan dengan perilaku disruptif pada remaja.

Memperkuat temuan tersebut Hale, Raaijimakers, Van Hoof dan Meuus (2011) mengungkapkan bahwa agresivitas dan kenakalan remaja salah satunya disebabkan oleh bagaimana anak mempersepsikan ekspresi emosi orangtua mereka. Hal ini menunjukkan bahwa secara umum ekspresi emosi keluarga dapat berperan terhadap munculnya berbagai jenis psikopatologi atau gangguan yang dialami oleh anak dan remaja, termasuk perilaku disruptive.

Selanjutnya, meskipun ditemukan ada pengaruh dari ekspresi emosi keluarga dan persepsi hubungan orangtua anak sebagai variabel prediktor terhadap munculnya perilaku disruptif tetapi sumbangan efektif yang diberikan sangat kecil 5,3\%. Jika mengacu kepada kajian literatur yang dilakukan, disebutkan bahwa faktor yang berperan terhadap munculnya perilaku disruptive sangat beragam, yaitu faktor keluarga, biologis atau genetis, psikologis atau temperamen dan lingkungan (American Psychiatric Association, 2013 \& Nasrizulhaidi, Minauli \& Yusuf, 2015). Kecilnya kontribusi pada penelitian ini disebabkan oleh kedua variabel prediktor yang diuji hanya berasal dari satu faktor keluarga saja, yaitu ekspresi emosi dan persepsi hubungan orangtua-anak yang artinya faktor tersebut hanyalah sebagian kecil dari keseluruhan faktor yang ada.

Pada analisis yang dilakukan terpisah, tidak ditemukannya hubungan antara persepsi hubungan orangtua-anak terhadap ibu sedangkan persepsi hubungan orangtua-anak terhadap ayah berperan terhadap munculnya gejala perilaku disruptif remaja yang disebabkan oleh adanya temuan kelemahan dalam proses pengumpulan data penelitian. Namun, secara teoritis tidak ditemukannya hubungan antara persepsi hubungan orangtua-anak dan munculnya gejala perilaku disruptif remaja disebabkan oleh faktor kualitas hubungan yang terjalin antara orangtua-anak kurang terjalin dengan baik, di mana hal ini dapat dilihat pada kedekatan orangtua-anak dalam kehidupan sehari-hari. Menurut Fatmasari dan Faturochman (2013) alasan kuat kedekatan dengan ayah dan ibu terbentuk karena adanya kasih sayang antar keduanya kepada anak yang didasarkan kepada peran masing-masing. Peran orangtua secara garis besar terbagi menjadi tiga yaitu, ayah-ibu memahami dan menyayangi berdasarkan perannya dalam keluarga Jawa disebut asih, sedangkan ayah membimbing (asah), dan ibu menemani (asuh). Bentuk kedekatan dengan ayah terlihat dari kegiatan bersifat informal dan rekreatif, dan dengan ibu berkaitan dengan tugas rumah tangga dan pengasuhan.

Berbeda dengan pendapat tersebut Hakim, Thontowi, Yuniarti, dan Kim (2012) menyebutkan bahwa peran ayah di dalam keluarga lebih mengarah kepada asah sedangkan ibu asih dan asuh. Berdasarkan pendapat tersebut ayah dianggap berkewajiban mengajarkan nilai agama sosial budaya dan bertanggung jawab terhadap pendidikan anak seperti memberikan saran dan bimbingan terkait apa yang boleh dan tidak boleh dilakukan (asah), sedangkan ibu dianggap berkewajiban untuk menyediakan afeksi dan perhatian secara penuh kepada 
anak (asih) serta memperhatikan dan memenuhi kebutuhan anak sehingga tumbuh dan berkembang secara sehat (asuh) (Fatmasari \& Faturochman, 2013).

Jika dilihat secara maknawi, peran ibu yang cenderung asuh dan asih dalam praktiknya sangat dekat dengan sebuah konsep ngemong dalam keluarga suku Jawa, yaitu cara khusus bagaimana orangtua memperlakukan anak sehingga mereka merasa tent rem (tenang dan damai). Fenomena temuan di lapangan ini menjelaskan bahwa persepsi hubungan orangtua-anak terhadap ibu tidak terbukti berperan terhadap munculnya gejala perilaku disruptive remaja. Pernyataan tersebut kemudian diperkuat oleh Subandi (2011), bahwa konsep ngemong dalam praktik pengasuhan keluarga di Jawa merupakan salah satu bentuk dari dukungan keluarga yang membantu menjadi faktor protektif terhadap munculnya atau kekambuhan suatu gangguan mental.

Adanya perpaduan antara asih, asuh dan ngemong yang melekat pada sosok ibu merupakan dua kolaborasi berbau kultur yang dapat membentuk persepsi hubungan orangtua-anak yang positif dan memperkuat terbentuknya faktor protektif di dalam diri anak. Inilah kemudian yang menjadi alasan anak tidak mengembangkan perilaku disruptive meskipun telah memiliki faktor risiko terhadap munculnya gejala perilaku disruptive tersebut. Hal ini sejalan dengan Kim, Yang, dan Hwang (2010) yang menyebutkan bahwa peran dan tanggung jawab ibu berimplikasi pada kesejahteraan psikologis dan fisik seorang anak. Dengan demikian, berdasarkan temuan pada penelitian ini, persepsi hubungan orangtuaanak terhadap ibu dapat menjadi faktor protektif terhadap munculnya gejala perilaku disruptive remaja.

Namun demikian, pada penelitian ini persepsi hubungan orangtua-anak terhadap ibu yang diasumsikan dapat menjadi faktor protektif tidak cukup kuat untuk membuat anak tidak mengembangkan perilaku disruptif. Hal ini disebabkan ada berbagai faktor lain yang cukup kuat berperan memperparah munculnya perilaku disruptive pada remaja yaitu, kontrol yang dilakukan oleh ayah, ekspresi emosi keluarga dan berbagai variabel lainnya yang tidak ikut diteliti menjadi fokus kajian pada penelitian ini seperti status sosial ekonomi, kemiskinan, dan berbagai jenis faktor pengasuhan yang lainnya.

Selanjutnya, untuk menjelaskan keterkaitan persepsi hubungan orangtua-anak terhadap ayah dan munculnya gejala perilaku disruptif pada remaja dapat dilihat dari peran ayah yang lebih condong kepada asah di mana secara maknawi praktiknya lekat dengan aspek kontrol yang ada pada dimensi persepsi hubungan orangtua-anak. Menurut Fatmasari dan Faturochman (2013) makna asah pada peran ayah adalah sebuah kewajiban yang harus dilakukan ayah untuk mengajarkan nilai agama sosial budaya dan bertanggung jawab terhadap pendidikan anak seperti memberikan saran dan bimbingan terkait apa yang harus dilakukan atau tidak. Berdasarkan pemaparan tersebut ada aspek kontrol di dalamnya. Inilah alasan kenapa anak kemudian memunculkan perilaku disruptive. Menurut Peisah, Brodaty, Luscombe, Kruk \& Anstey (1999) jika dilihat dari aspek persepsi hubungan orangtua-anak, kontrol merupakan hal yang paling relevan yang ada pada ayah dan lebih positif memunculkan psikopatologi pada anak dibandingkan aspek lainnya seperti regards dan responsibility yang juga ada pada ibu.

Untuk menjelaskan proses munculnya gejala perilaku disruptif pada remaja, penelitian ini menggunakan paradigma pendekatan biopsikososial, yaitu sebuah pendekatan yang memandang adanya interaksi dari faktor biologi, psikologis, dan sosial budaya dalam menjelaskan perkembangan gangguan mental dalam bentuk diathesis-stress model. Pada model ini disebutkan bahwa individu memiliki kerentanan tertentu terhadap gangguan fisik maupun psikologis meskipun 
pada beberapa kasus kerentanan tersebut belum cukup untuk membuat seseorang mengalami gangguan. Hal ini disebabkan munculnya sebuah gangguan sifatnya sangat komprehensif, tidak hanya dapat dimunculkan oleh satu faktor saja seperti faktor biologis atau genetik akan tetapi ada berbagai faktor lain yang juga turut berkontribusi seperti stres yang disebabkan oleh faktor sosial (Beidel, Bulik \& Stanley, 2012; Hoeksema, 2011).

Remaja yang memiliki gejala perilaku disruptive memiliki suatu kerentanan yang dibawa atau diturunkan secara genetis atau sifatnya biologis, hal ini sesuai Stadler, Poustka, dan Sterzer (2010) bahwa faktor genetik dan neurobiologis berperan terhadap perkembangan perilaku disruptif sehingga dalam penanganannya harus memperhatikan kedua hal tersebut. Namun demikian, adanya kerentanan yang dialami oleh individu belum cukup untuk kemudian memunculkan sebuah perilaku yang disruptive. Saat kerentanan yang dimiliki individu berinteraksi dengan stres yang dirasakan anak akbibat adanya trauma atau persoalan-persoalan hidup yang dimunculkan dari lingkungan keluarga berupa ekspresi emosi orangtua dan persepsi hubungan orangtua-anak maka akan semakin memperkuat adanya kerentanan tersebut untuk memunculkan perilaku disruptif.

Pada bagan 1 dapat diketahui bahwa remaja yang memiliki gejala perilaku disruptif memiliki suatu kerentanan yang dibawa atau diturunkan secara genetis atau sifatnya biologis, hal ini sesuai Stadler, Poustka dan Sterzer (2010) bahwa faktor genetik dan neurobiologis berperan terhadap perkembangan perilaku disruptive sehingga dalam penanganannya harus memperhatikan kedua hal tersebut. Namun demikian, adanya kerentanan yang dialami oleh individu belum cukup untuk kemudian memunculkan sebuah perilaku yang disruptif. Saat kerentanan yang dimiliki individu berinteraksi dengan stres yang dirasakan anak akibat adanya trauma atau persoalan-persoalan hidup yang dimunculkan dari lingkungan keluarga berupa ekspresi emosi orangtua dan persepsi hubungan orangtua-anak maka akan semakin memperkuat adanya kerentanan tersebut untuk memunculkan perilaku disruptive.

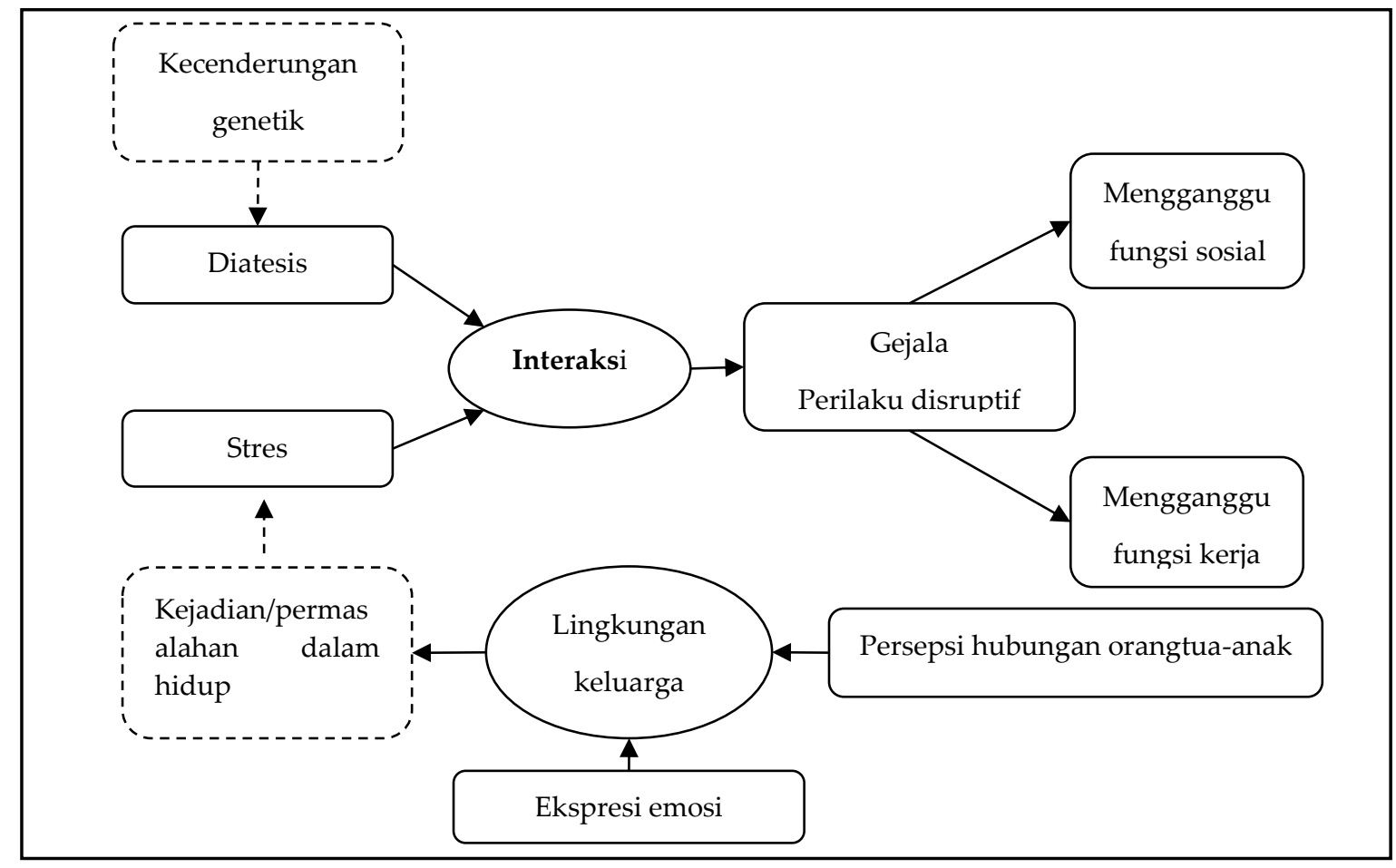

Gambar 1. Model Diathesis-Stress dalam memprediksi munculnya gejala perilaku disruptive 
Pada Gambar 1 dapat diketahui bahwa remaja yang memiliki gejala perilaku disruptif memiliki suatu kerentanan yang dibawa atau diturunkan secara genetis atau sifatnya biologis, hal ini sesuai Stadler, Poustka, dan Sterzer (2010) bahwa faktor genetik dan neurobiologis berperan terhadap perkembangan perilaku disruptif sehingga dalam penanganannya harus memperhatikan kedua hal tersebut. Namun demikian, adanya kerentanan yang dialami oleh individu belum cukup untuk kemudian memunculkan sebuah perilaku yang disruptif. Saat kerentanan yang dimiliki individu berinteraksi dengan stres yang dirasakan anak akibat adanya trauma atau persoalan-persoalan hidup yang dimunculkan dari lingkungan keluarga berupa ekspresi emosi orangtua dan persepsi hubungan orangtua-anak maka akan semakin memperkuat adanya kerentanan tersebut untuk memunculkan perilaku disruptif.

Menurut Peris dan Miklowitz (2015) faktor lingkungan keluarga dengan model "toxic family stress" tanpa adanya faktor protektif membuat suatu kerangka pemikiran bahwa ekspresi emosi orangtua dan persepsi hubungan orangtua-anak jika berinteraksi dengan kerentanan biologis individu akan meningkatkan omset penyakit atau kekambuhan suatu gangguan. Namun demikian, jika anak memiliki faktor protektif yang kuat ketika terjadi interaksi antara kerentanan yang dimiliki individu dan faktor stres akibat lingkungan keluarga yang negatif maka kemungkinan anak memunculkan perilaku disruptive sangat minim. Faktor-faktor protektif tersebut dapat berupa karakteristik pribadi anak yang positif, hubungan keluarga dan pertemanan yang kondusif serta keterlibatan dalam berbagai aktivitas yang menyenangkan (Vanderbilt-adriance dkk., 2015). Adapun karakteristik anak yang dianggap menjadi faktor protektif terhadap berbagai perilaku beresiko yang dimunculkan adalah bagaimana cara anak mengontrol dirinya (self control) (Liu, Wang, \& Tian, 2019).

\section{SIMPULAN}

Hasil penelitian menunjukkan bahwa ekspresi emosi keluarga dan persepsi hubungan orangtua-anak memiliki peranan penting terhadap munculnya gejala perilaku disruptive remaja. Kedua variabel prediktor tersebut terbukti memiliki hubungan positif terhadap munculnya perilaku disruptif remaja. Baik itu ekspresi emosi ibu, ekspresi emosi ayah, persepsi hubungan orangtuaanak kepada ibu dan persepsi hubungan orangtua-anak kepada ayah. Dengan demikian dapat disimpulkan bahwa masalah perilaku yang dimunculkan oleh anak dapat dipengaruhi oleh adanya ekspresi emosi kedua orangtua mereka dan persepsi hubungan orangtua-anak yang tidak baik terhadap kedua orangtua mereka.

\section{DAFTAR PUSTAKA}

Amaresha, A. C., \& Venkatasubramanian, G. (2017). Expressed emotion in schizophrenia: An overview. Indian Journal of Psychological Medicine, $34(1)$, 12-20. doi:10.4103/02537176.96149

American Psychiatric Association. (2013). Diagnostic and statistical manual of mental disorders (5 ed). Arlington, VA: American Psychiatric Association.

Asarnow, J. R., Tompson, M., Woo, S., \& Cantwell, D. P. (2001). Is expressed emotion a specific risk factor for depression or a nonspecific correlate of psychopathology? Journal of Abnormal Child Psychology, 29(6), 573-583. doi: 10.1023/A:101223 7411007.

Asizah. (2015). Children disruptive behavior well-being: Pentingnya hubungan anak dan orangtua. Psychology Forum. Universitas Muhammadiyah Malang. Diunduh dari: http://mpsi. umm.ac.id/files/file/4654\%20Asizah. 
pdf

Badan Pusat Statistik. (2010). Profil kriminalitas remaja. Diakses dari https://www.bps.go.id/publication/20 10/12/30/703312c2e156dd5bbebcb8c c/profil-kriminalitas-remaja2010.html

Badan Pusat Statistik. (2014). Statistik kriminal. Diakses dari https://www.bps.go.id/publication/20 14/12/22/4567bfb67f38ee79c535439 b/statistik-kriminal-2014.html

Bader, S. H. Barry, T. D., \& Hann, J. H. (2015). The relation between parental expressed emotion and externalizing behaviors in children and adolescents with an autism spectrum disorder. Focus on Autism and Other Developmental Disabilities. 30(1), 23-34. doi:10. $1177 / 1088357614523065$.

Beidel, D. C., Bulik, C. M., \& Stanley, M. A. (2012). Abnormal psychology (2 ed).New Jersey,NJ: Pearson Education, Inc.

Berkout, O. V., Young, J. N., \& Gross, A. M. (2011). Mean girls and bad boys: Recent research on gender differences in conduct disorder. Aggression and Violent Behavior, 16(6), 503-511. doi: 10.1016/j.avb. 2011.06.001

Boger, K. D., Tompson, M. C., BriggsGowan, M. J., Pavlis, L. E., \& Carter, A. S. (2008). Parental expressed emotion toward children: prediction from early family functioning. Journal of family psychology : JFP : journal of the Division of Family Psychology of the American Psychological Association (Division 43), 22(5), 784-788. doi:10.1037/a0013251
Buitelaar, J. K., Smeets, K. C., Herpers, P., Scheepers, F., Glennon, J., \& Rommelse, N. N. (2013). Conduct disorders. European Child \& Adolescent Psychiatry, 22(1), 49-54. doi:10.1007/s00787-012-0361-y

Bulotsky-Shearer, R. J., Dominguez, X., Bell, E. R., Rouse, H. L., \& Fantuzzo, J. W. (2010). Relations between behavior problems in classroom social and learning situations and peer social competence in head start and kindergarten. Journal of Emotional and Behavioral Disorders, 18(4), 195-210. doi:10.1177/1063426609351172

Carra, G., Cazzullo, C. L., \& Clerici, M. (2012). The association between expressed emotion, illness severity and subjective burden of care in relatives of patients with schizophrenia: Findings from an Italian population. BMC Psyciatry, 12(140), 1-8. doi:10.1186/1471244X-12-140

Christenson, J. D., Crane, D. R., Malloy, J., \& Parker, S. (2016). The cost of oppositional defiant disorder and disruptive behavior: A review of the literature. Journal of Child and Family Studies, 25, 2649-2658. doi:10.1007/s10826-016-0430-9

Dobmeier, R., \& Moran, J. (2008). Dealing with disruptive behavior of adult learners. New Horizons in Adult Education and Human Resource Development, 22(2), 29-54. doi:10.1002/nha3.10306

Fatmasari, A. E., \& Faturochman. (2013). Dinamika kedekatan hubungan orangtua-anak: Perbedaan kedekatan ayah-ibu dengan anak laki-laki dan anak perempuan tahap remaja akhir pada keluarga Jawa (Master thesis, Universitas Gadjah 
Mada, Yogyakarta, Indonesia).

Field, A. (2011). Discovering statistics using SPSS. Los Angeles, CA: Sage Publications Ltd.

Frank-briggs, A. I., Alikor, E. A. D., \& Harcourt, P. (2008). Conduct disorder amongst children in an urban school in Nigeria. The Nigerian Health Journal, 8(3-4), 44-47. Diunduh dari https://www.ajol.info/index.php/nhj/a rticle/view/90803

Goodman, R., Meltzer, H., \& Bailey, V. (1998). The strengths and difficulties questionnaire: A pilot study on the validity of the selfreport version. European Child \& Adolescent Psychiatry, 7(3), 125130. doi:10.1007/s007870050057

Hale, W. W., Crocetti, E., Nelemans, S. A., Branje, S. J. T., van Lier, P. A. C., Koot, H. M., \& Meeus, W. H. J. (2016). Mother and adolescent expressed emotion and adolescent internalizing and externalizing symptom development: A six-year longitudinal study. European Child and Adolescent Psychiatry, 25(6), 615-624. doi:10.1007/s00787-0150772-7

Hale, W. W., Raaijmakers, Q. A. W., Van Hoof, A., \& Meeus, W. H. J. (2011). The predictive capacity of perceived expressed emotion as a dynamic entity of adolescents from the general community. Social Psychiatry and Psychiatric Epidemiology, 46(6), 507-515. doi:10.1007/s00127-0100218-y

Han, Z. R., \& Shaffer, A. (2014). Maternal expressed emotion in relation to child behavior problems: Differential and mediating effects. Journal of Child and Family Studies, 23(8), 14911500. doi:10.1007/s10826-014-9923-
6

Hammerton, G., Murray, J., Maughan, B. et al. (2019). Childhood behavioural problems and adverse outcomes in early adulthood: A comparison of brazilian and british birth cohorts. Journal of Developmental and LifeCourse Criminology https://doi.org/10.1007/s40865-01900126-3

Hastings, R. P., \& Lloyd, T. (2007). Expressed emotion in families of children and adults with intellectual disabilities. Mental Retardation Developmental Disabilities, 13(4), 339-345. doi:10.1002/mrdd

Hoeksema, S. N. (2011). Abnormal psychology (5 ed.). New York, NY: McGraw-Hill.

Huang, C. Y., Hsieh, Y. P., Shen, A. C., Wei, H. S., Feng, J. Y., Hwa, H. L., \& Feng, J. Y. (2019). Relationships between parent-reported parenting, child-perceived parenting, and children's mental health in taiwanese children. International Journal of Environmental Research And Public Health, 16(6), 1-14. doi:10.3390/ijerph16061049

Kanter, J., Lamb, H. R., \& Loeper, C. (1987). Expressed emotion in families: A critical review. Hospital and Community Psychiatry, 38(4), 374-380. doi:10.1176/ps.38.4.374

Kim, U., Yang, K. S., \& Hwang, K. K. (2010). Indigeneous and cultural psychology: Memahami orang dalam konteksnya. Yogyakarta: Pustaka Pelajar.

Kronenberg, L. M., Goossens, P. J. J., van Busschbach, J. T., van Achterberg, T., \& van den Brink, W. (2016). Burden and expressed emotion of 
caregivers in cases of adult substance use disorder with and without attention deficit/hyperactivity disorder or autism spectrum disorder. International Journal of Mental Health and Addiction, 14(1), 49-63. doi:10.1007/s11469-015-9567-9

Liu, L., Wang, N., \& Tian, L. (2019). The parent-adolescent relationship and risk-taking behaviors among chinese adolescents: the moderating role of self-control. Frontiers in psychology, 5(10), doi:10.3389/fpsyg.2019.00542

Loeber, R., Burke, J.D., \& Pardini, D.A.(2009). Development and etiology of disruptive and delinquent behavior. Annual Review of Clinical Psychology, 5(1), 291-310. doi:10.1146/annurev.clinpsy.032408. 153631

Matthys, W., \& Lochman, J. E. (2010). Oppositional defiant disorder and conduct disorder in childhood. John Wiley \& Sons, Ltd.

McCarty, C. A., Lau, A. S., Valeri, S. M., \& Weisz, J. R. (2004). Parent-child interactions in relation to critical and emotionally over involved expressed emotion (EE): Is EE a proxy for behavior? Journal Abnormal Child Psychology, 32(1), 83-93. doi:10.1023/B:JACP.0000007582.61 $879.6 f$

Nasrizulhaidi., Minauli, I., \& Yusuf E. A. (2015). Efektivitas anger management training untuk menurunkan agresivitas pada remaja disruptive behavior disorder. Jurnal Psikologi, 11(1), 12-18.

Njango, E., Merecia, S., \& Christine, W. (2016). Family emotional overinvolvement and relapse among inpatient alcoholics in Nairobi,
Kenya. IOSR Journal of Humanities and Social Science, 21(7), 44-50. doi:10.9790/0837-2107014450

Odgers, C. L., Moffitt, T. E., Broadbent, J. M., Dickson, N., Hancox, R. J., Harrington, H., ... Caspi, A. (2008). Female and male antisocial trajectories: From childhood origins to adult outcomes. Development and Psychopathology, 20(2), 673-716. doi:10.1017/S0954579408000333

Peisah, C., Brodaty, H., Luscombe, G., Kruk, J., \& Anstey, K. (1999). The parent adult-child relationship questionnaire (PACQ): The assessment of the relationship of adult children to their parents. Journal Aging \& Mental Health, 3(1), 2338.doi:10.1080/13607869956415

Peris, T. S., \& Miklowitz, D. J. (2015). Parental expressed emotion and youth psychopathology: New directions for an old construct. Child Psychiatry Human Development, 46(6), 863-873. doi:10.1007/s10578014-0526-7

Pitzer, L., Fingerman, K. L, \& Lefkowitz, E. S. (2011). Development of the parent adult relationship questionnaire (PARQ). International Journal Aging Development, 72(2), 111-135. doi:10.2190/AG.72.2.b

Pringsheim, T., Hirsch, L., Gardner, D., \& Gorman, D. A. (2015). The pharmacological management of oppositional behaviour, conduct problems, and aggression in children and adolescents with attention-deficit hyperactivity disorder, oppositional defiant disorder, and conduct disorder: A systematic review and meta-analysis. Part 2: antipsychotics and traditional mood stabilizers. Canadian Journal of Psychiatry. Revue Canadienne De 
Psychiatrie, 60(2), 52-61. doi:10.1177/070674371506000203

Przeworski, A., Zoellner, L. A., Franklin, M. E., Garcia, A., Freeman, J., March, J. S., \& Foa, E. B. (2012). Maternal and child expressed emotion as predictors of treatment response in pediatric obsessive-compulsive disorder. Child Psychiatry and Human Development, 43(3), 337-353. doi:10.1007/s10578011-0268-8

Reinke, W. M., \& Herman, K. C. (2002). Creating school environments that deter antisocial behaviors in youth. Psychology in the Schools, 39(5), 549-559. doi:10.1002/pits. 10048

Shepherd, T. (2010). Working with students with emotional behavior disorder characteristic and behavior disorder. New Jersey, NJ: Pearson Education Inc.

Schmidt, R., Tetzlaff, A., \& Hilbert, A. (2015). Perceived expressed emotion in adolescents with binge-eating disorder. Journal of Abnormal Child Psychology, 43(7), 1369-1377. doi:10.1007/s10802-015-0015-

Shimodera, S., Yonekura, Y., Yamaguchi, S., Kawamura, A., \& Mizuno, M. (2012). Bipolar I disorder and expressed emotion of families: A cohort study in Japan. Open Journal of Psychiatry, 2(4), 258-261. doi:10.4236/ojpsych.2012. 24035

Stadler, C., Poustka, F., \& Sterzer, P. (2010). The heterogeneity of disruptive behavior disorders-implications for neurobiological research and treatment. Frontiers in Psychiatry, $1(21)$, 1-14. doi:10.3389/fpsyt.2010.00021

Subandi, M. A. (2011). Family expressed emotion in a Javanese cultural context. Culture, Medicine and Psychiatry, 35(3), 331-346. doi:10.1007/s11013-011-9220-4

Tam, C. L., Lee, T. H., Kumarasuriar, V., \& Har, W. M. (2012). Parental authority, parent-child relationship and gender differences: A study of college students in the Malaysian context. Australian Journal of Basic and Applied Science, 6(2), 182-189. Diunduh dari http://ajbasweb.com/old/ajbas/2012/F ebruary/182-189.pdf

Tompson, M. C., Pierre, C. B., Boger, K. D., McKowen, J. W., Chan, P. T., \& Freed, R. D. (2010). Maternal depression, maternal expressed emotion, and youth psychopathology. Journal of Abnormal Child Psychology, 38(1), 105-117. doi:10.1007/s10802-009-9349-6

Vanderbilt-Adriance, E., Shaw, D. S., Brennan, L. M., Dishion, T. J., Gardner, F., \& Wilson, M. N. (2015). Child, family, and community protective factors in the development of children's early conduct problems. Family Relations, 64(1), 6479. doi:10.1111/fare.12105

Vasconcelos e Sa, D., Wearden, A., \& Barrowclough, C. (2013). Expressed emotion, types of behavioural control and controllability attributions in relatives of people with recent-onset psychosis. Social Psychiatry and Psychiatric Epidemiology, 48(9), 1377-1388. doi:10.1007/s00127-0130659-1

Wenar, C., \& Kerig, P. (2012). Developmental psychopathology from infancy through adolescent (6 Revised ed.). New York, NY: McGraw-Hill Inc.

Wiguna, T., Manengkei, P. S. K., Pamela, 
C., Rheza, A. M., \& Hapsari, W. A. (2010). Masalah emosi dan perilaku pada anak dan remaja di poliklinik jiwa anak dan remaja RSUPN Dr. Ciptomangunkusumo (RSCM). Jurnal Sari Pediatri, 12(4), 270-277.

Yu, D. S. F., Kwok, T., Choy, J., \& Kavanagh, D. J. (2016). Measuring the expressed emotion in Chinese family caregivers of persons with dementia: Validation of a Chinese version of the family attitude scale. International Journal of Nursing Studies, (55), 50-59. doi: 10.1016/j. ijnurstu.2015.11.0
Zanetti, A. C. G., Vedana, K. G. G., Gherardi-Donato, E. C. da S., Galera, S. A. F., Martin, I. dos S., Tressoldi, L. de S., \& Miasso, A. I. (2018). Emoção expressa de familiares e recaídas psiquiátricas de pacientes com diagnóstico de esquizofrenia [Expressed emotion of family members and psychiatric relapses of patients with a diagnosis of schizophrenia]. Revista da Escola de Enfermagem USP, 52, 1-7. doi: http://dx.doi.org/10.1590/S1980220X2016042703330 